\title{
Julian Barnes: Toward a Minor History
}

Julian Barnes ve Minör Tarih

\author{
Rahime Çokay Nebioğlu \\ Ankara Hacı Bayram Veli University, Turkey
}

\begin{abstract}
Julian Barnes is predominantly known for his radical experiment with the notion of history. He uses and abuses official accounts of history in order to register a history of the unvoiced in his novels. In his attempt to foreground what is unregistered in history, he often ends up embracing a very strong dystopian mode, depicting a world full of terrors, disasters and crises. As this article argues, he presents a "hystopia," that is, a history of dystopia or history as a dystopia. In Barnes, history is a hystopia not only in the sense that it is full of catastrophes, but also in the sense that it is subjective, unreliable and even fascistic in imposing only a single version of the past. Barnes creates alternative histories which downplay the absoluteness of the official accounts and create ruptures in the causal lines of hystopia. In this sense, these alternative accounts can be seen as "minor" history in Deleuzian terms, which is nonlinear, rhizomatic and eventful. Against this background this article aims to elaborate on these new notions of "hystopia" and "minor history" in Barnes's novels, addressing the relation of his understanding of history to minoritarian politics in the light of Deleuze and Guattari's philosophy.
\end{abstract}

Keywords: Julian Barnes, historiography, minor literature, minoritarian politics, Deleuze and Guattari

Öz

Julian Barnes çoğunlukla tarih kavramı üzerinde radikal deneyler gerçekleştiren bir yazardır. Yazar, romanlarında susturulmuş olanların tarihini ön plana çıkarabilmek maksadıyla resmi tarihi üzerinde oynar. Yazarın resmi tarihe dahil edilmeyenleri gün yüzüne çıkarırken, son derece distopik bir mod yakaladığı ve dünyayı terör, felaket ve krizlerle dolu bir dünya olarak resmettiği gözlemlenir. Bu çalışma, yazarın eserlerinde tarihi bir distopya ya da bir distopyalar tarihi olarak sunduğunu savunmakta ve yazarın tarih anlayıșını "hystopia" olarak adlandırmaktadır. Barnes'ın eserlerinde tarih hem felaketlerle dolu oluşu hem de geçmişin yalnızca tek bir temsilini empoze etme gayesiyle son derece öznel, güvenilmez ve faşist bir şekilde yaratılması dolayısıyla bir "hystopia"dır. Ancak Barnes bir distopya olarak tarihin keskinliğini ve kesinliğini sorunsallaştıracak ve çizgisel yapısında kırılmalar yaratacak alternatif tarihlere de yer verir. Bu çalışma bu alternatif tarihleri, Deleuzyen bir çerçevede çizgisel olmayan, rizomatik ve olaysal olarak tanımlanabilecek "minör" tarih olarak adlandırmakta ve Deleuze ve Guattari'nin felsefesi ışığında Barnes'ın tarih anlayıșının minör politikalarla olan yakınlığını ortaya koyarak çalışmada öne sürülen "hystopia" ve "minör tarih" kavramlarını derinlemesine ele almayı amaçlamaktadır.

Anahtar Kelimeler: Julian Barnes, tarih yazımı, minör edebiyat, minör politikalar, Deleuze ve Guattari

CUJHSS, December 2020; 14/2: 252-262. DOI: 10.47777/cankujhss.848935

(C) Çankaya University ISSN 1309-6761 Printed in Ankara

Submitted: May 20, 2020; Accepted: Oct 4, 2020

ORCID\#: 0000-0003-4114-9437; rhmcky@gmail.com 
The aim of this article is to inquire into how history is treated by Julian Barnes through the new notions of hystopia and minor history and possible political implications of his treatment of history in the light of Deleuze and Guattari's philosophy. In its basic outline, this inquiry will be guided by three major questions. The first question is "What is history in the most traditional sense of the word?" and/or "How does the traditional treatment of history turn out to dystopian?". The second is "What is the actual relation between time and history?". The last one is "How do alternative histories function?", or to be more precise, "How can we relate alternative histories to the idea of revolution in a Deleuzian sense?". In answering these questions in relation to the notions of hystopia and minor history, this article will focus on a limited corpus, four novels of Barnes, A History of the World in 10 1/2 Chapters, Flaubert's Parrot, England, England and The Sense of an Ending. These four novels will be helpful in conceptualising the new notions of hystopia and minor history while simultaneously delineating Barnes's position in minoritarian politics.

Julian Barnes has engaged with the notion of history throughout his literary career. His engagement with history has often been linked to a postmodernist tendency to subvert it as a grand narrative. Many scholars have interpreted his works as typical examples of postmodernist fiction where the process of historiography is depicted to underline the blurring boundaries between historical fact and fiction (Childs 9; Holmes 15; Guignery 46; Head 16). Despite these overwhelming attempts to relate Barnes's literary position to postmodernism, however, Barnes himself openly rejects his affiliation with postmodernist fiction (qtd. in Freiburg and Schnitker 52). This necessitates a novel insight into Barnes and his experiments with historiography. At this point, Deleuze and Guattari's theories, particularly their counter-arguments against Hegelian understanding of history, could be a guiding spirit to revisit Barnes's literary stance.

History occupies a sophisticated position in Barnes. Barnes employs two forms of history in his work, hystopia and minor history. Hystopia is a term that this article coins to define and describe what history is in the most traditional sense of the word. Hystopia is a coinage whose meaning hovers between history and dystopia, foregrounding the idea of a history of dystopia and history as dystopia. History is a hystopia in Barnes firstly because he patently considers it to be full of catastrophes, disasters, terrors and crises. Most of his works proceed through cataclysms, outrages and disheartening facts, and are governed by a strong sense of pessimism and melancholia. His iconic novel $A$ History of The World in 10 1/2 Chapters, for instance, chronicles the disasters and tragic events that have taken place since the Genesis. It jaunts from human cruelty performed by Noah and his family in the first chapter to religious terrorism in the second, from religious wars in the third chapter to nuclear disaster in the fourth, from shipwreck tragedies in the fifth and the sixth to the Holocaust in the seventh chapter. It finally ends with a heaven that "becomes a cyclical living hell, an endless present" in Buxton's words (82). The entire course of history repetitively encounters endless series of disasters; thus, it suggests a circular ongoingness of dystopian events. As Barnes himself points 
out in his History of the World, "[h]istory just burps, and we taste again that raw-onion sandwich it swallowed centuries ago" (241). The repetitiveness in the form of history signals our second query, "the problematic relation between time and history". Barnes has neither a "static view of history" nor a "linear view of history" (Guignery "History" 57). History is for Barnes repetitive, but it is not a static repetitiveness, or to put it more simply, it is not the repetition of the same. Each time it repeats, it comes along with a series of differences. That is, there is a kind of newness or a variation in each repetition in a Deleuzian sense.

The idea of newness in repetition lies in the relation between the virtual and the actual in Deleuze's philosophy of time, strongly influenced by Bergson. In his work Difference and Repetition (1968), Deleuze talks about three passive syntheses of time through which we could fully comprehend the intricate link between the virtual and the actual and their relation to the notion of history. The first synthesis of time suggests the idea of living, organic and polytemporal present on the grounds that the past and the future are always necessarily a part of the present. As Deleuze underlines, "[t]he past and the future do not designate instants distinct from a supposed present instant, but rather the dimensions of the present itself in so far as it is a contraction of instants. The present does not have to go outside itself in order to pass from past to future" (71). On the contrary, it is a dynamic interpenetration of the past and the future. The second synthesis elaborates more on the nature of the present. In this synthesis, Deleuze puts forward the idea of a present that simultaneously passes. This is to say that we have a continuous present where it constantly falls into the past. Such an understanding of a present that is continuously passing corresponds to the simultaneity of the past and the present. The past is contemporaneous with the present as they occur at the very same time. As Deleuze himself clarifies, "[t]he present and former presents are not [...] like two successive instants on the line of time; rather, the present one necessarily contains an extra dimension in which it represents the former and also represents itself" (71). Through these two syntheses, we arrive at a third synthesis of time whereby time comes "out of joint" (88). Time out of joint means "demented time," time freed from "its relation to movement" towards the future, "time presenting itself as an empty and pure form" (88). It is a split in the linearity of time so it is indeed "the time of what Deleuze calls "the event"' (Bogue 41), and "the condition for actions that drive towards the new" (Williams 102). The production of the new can be explained through a new understanding of the eternal return and repetition. Affirming Nietzschean understanding of the eternal return of the same, Deleuze suggests an eternal return of difference. The past does not repeat itself in the present in the very same way it happened but it returns to the present in pure difference. The return of difference is the harbinger of the production of the new in the future, which simultaneously makes both the past and the future an inseparable part of the present.

These three syntheses resonate with the relation between the actual and the virtual: The past is not a series of events that once happened but a virtuality 
that always necessarily manifests itself in the present. Similarly, the present is not purely in itself but a threshold between the past, the present and the future. On the one hand, it is the actual since it is the actualisation of the past as the virtual. On the other hand, it is the virtual since it keeps passing and promising the production of the new as a repetition of difference in the future. This is tantamount to saying that the present actualises while at the same time it virtualises.

This understanding of time would be the answer to the very question Barnes poses in Flaubert's Parrot, "Does the world progress? Or does it merely shuttle back and forth like a ferry?" (105). Apparently, the answer is the latter! Neither the world nor history follows a linear progression in Barnes's understanding. The history of the world is thus nothing but a repetition of the virtual past in pure difference. It continuously shuttles back and forth between the past, the present and the future. It is what Bergson calls a "cone" (162), a cone full of renewed and renewable disasters. In A History of the World, the repetitive oscillation between the past, the present and the future is portrayed through recurrent patterns and events in the chapters. It is not surprising to see the woodworm sneaking into Noah's ark around 3000 BC in one chapter standing trial in the 16th century in another. The return of the disasters in pure difference could best be observed in the final chapter of the novel. This last chapter entitled "The Dream" begins as a utopian promise of paradise. But the ultimate telos of the history of the world, that is, paradise, somehow turns into an endless nightmare. In other words, utopia goes wrong. This ironic inconclusion suggests that the past and the future simultaneously coexist since the residues of the virtual past are decisive of the future. In this case, the catastrophes of the past and the passing present are indeed nightmarish images of the future world since they would keep reappearing in the future only in different scenarios. This makes history literally a dystopia in the strictest sense of the word.

In Barnes's work, history is hystopia not only because it depicts a dystopian picture of the world but also because it is always controlled and manipulated by dominant discourses, which makes it utterly subjective, unreliable and even fascistic in imposing only a single version of the past. To begin with the first argument, Barnes frequently presents history as "the lies of the victors" or the lies of the "survivors" as he puts it in The Sense of an Ending (16). Noah's Ark, for instance, has always been a story of heroism and emancipation although it is indeed a story of tyranny in the stowaway's account as depicted in A History of the World. In a similar vein, the wreck of Medusa has often been portrayed as a story of miracle and the miraculous survivors although it is actually a story of cannibalism.

The disposability and malleability of history by dominant powers can be best understood through the relation between history and capitalism. Capitalism is, for Deleuze and Guattari, what "determines the conditions and the possibility for a universal history" (Anti-Oedipus 140). Universal history here stands for what this article calls "hystopia". History operates through the principle of 
axiomatisation just like everything else captured in capitalism. This is because capitalism tends to create its own origins by fabricating history in a teleological fashion through its State apparatus, namely through its despotic force. In this sense, history is strongly tied to capitalism since the capitalist social machine creates a state history that "describes an ordered succession of regimes" (Lampert 72). In capitalism, as Claire Colebrook puts it, "it no longer matters what circulates - whether it is money, goods, information, or even the feelgood messages of feminism, multiculturalism, [...] community [or history] - as long as there is constant exchange" (65). This intricate give-and-take relation of capitalism to history is perfectly depicted in Barnes's England, England. The Island Project in the novel sheds light upon the capitalist production of history as "an element of propaganda, of sales and marketing" (Barnes England 7). History and the national identity of England are first decoded from their initial positions and then reproduced and turned into a "pure market state" (187). Most critics consider this new market state as a "simulacrum" (Baudrillard 11) in Baudrillardian sense that is far removed from the reality and hence devoid of any authenticism (Guignery 108; Pateman 75). The capitalist production of history in the Island is a simulacrum not because it is an inauthentic copy of the real. Otherwise, this would mean that there is an outside actuality preceding simulation. History is a simulacrum only because it is a translation of the virtual in difference, which indeed testifies to the workings of the capitalist axiomatic.

This recalls the second argument of this article that history is subjective and unreliable. The subjectivity and unreliability of history lie primarily in the elusiveness of memory in a Bergsonian and Deleuzian sense. As Bergson argues, in each moment the present moves, history becomes bigger and bigger; and each subject shares the same bundle of history, a vast history. But each subject has a different "cone" of the past (162), that is, his own present/perception or his own duration. Duration is then memory in Bergson's view. In delineating how duration becomes memory, Deleuze relates both to "recollection-subjectivity" and "contraction-subjectivity" (Bergsonism 53). Recollections of the past are stored in duration and hence situated on the line of subjectivity. This means that memory is a production of the intricate relation between perception and recollection, between the past and the present. This makes memory inevitably subjective. The nature of memory is not only subjective but also elusive and fragmentary because it operates as "zigzag movements [between the past and the present], stages skipped here or there, [having] irreducible overall breaks" (Deleuze and Guattari $A$ Thousand Plateaus 428). As the main character Martha defines it in England, England, memory is not "a solid, seizable thing, which time, in its plodding, humorous way, might decorate down the years with fanciful detail - a gauzy swirl of mist, a thundercloud, a coronet - but could never expunge. A memory [is] by definition not a thing, it [is] a memory. A memory now of a memory a bit earlier of a memory before that of a memory way back then" (3). She calls it an "arranged lie" (4). Personal histories and even national histories predominantly rely on these arranged lies, which necessarily puts their 
reliability at stake. The subjective and unreliable nature of memory and history is very often touched upon in Barnes's work. Apart from England, England, the entire narrative of Flaubert's Parrot is structured upon the idea that historiography is a subjective process, showing the main protagonist, Braithwaite's individual attempt to write Flaubert's biography. In this attempt, Flaubert's parrot becomes a powerful metaphor of the impossibility of reaching out a "true story" (86), solid memories and the events as they really happened. The Sense of an Ending, likewise, experiments with the elusiveness of memory. The novel tells the story of the main protagonist, Tony Webster, who gradually comes to realize that the entire memory of his past is based upon a misunderstanding. This is to say that his entire personal history is nothing but a deceptive re-perception of the virtual past with the present self since "remembering isn't always the same as what you have witnessed" (The Sense of an Ending 1). As such, it is not surprising to see that history is referred to as "that certainty produced when the imperfections of memory meet the inadequacies of documentation" in the novel (17)

If history is a hystopia, it is also because it constantly attempts to hide its unreliability and subjectivity, which is another point frequently problematised in Barnes. As he puts it in The Sense of an Ending, "[t]he question of subjective versus objective interpretation, the fact that we need to know the history of the historian in order to understand the version that is being put in front of us," "[t]hat's one of the central problems of history" (12). What brings about this central problem is the idea of fabulation inherent to history. Fabulation, in the simplest sense of the word, is the act of making up stories. As Barnes notes in $A$ History of the World, you fabulate when "[y] ou make up a story to cover the facts you don't know or can't accept. You keep a few true facts and spin a new story" (109): "[you] fabulat[e] and convince [yourself] that fabulation is as true and concrete as what [you] 'really' kno[w]" (64). This means that fabulation helps to capture the past into a smooth narrative by filling the gaps between the events by legending or inventing stories. This is an act of moving the past from its Aionic nature to Chronos. The past, as previously discussed, remains on the line of Aion, where "past, present, and future [are] not at all three parts of a single temporality, but that they rather for[m] two readings of time, each one of which is complete and excludes the other" (Deleuze Logic of Sense 61). Thus, the past is not purely the past but rather exists infinitely in the present and the future as well. This means that the past by its very nature cannot be fully expressed in a chronological order. When it is somehow fabulated, it yields to Chronos, which corresponds to common-sense understanding of time, that is, time in linear progression (162-163). Chronos is the form of temporality which comes into being when the multi-layered and dynamic temporalities are translated into a "succession" (Deleuze and Guattari $A$ Thousand Plateous 430). This translation is indeed a despotic force that regulates the coexistence of different temporalities. Thus, it could be argued that it is simultaneously a translation into "hystopia" as well. To put it succinctly, hystopia is a "form of history which (1) proceeds in a linearchronological fashion, (2) obeys a standard ontology of cause-effect, (3) 
concerns itself with the task of representing the world [full of crises] (or its essence) and (4) is teleological" (Lundy 3).

Against hystopia, Julian Barnes comes up with an alternative form of history, namely, a minor history. Minor history is a coinage that this article offers to delineate Barnes's critical stance to linear, causal and teleological history and its manifestation in his novels. It is a term derived from Deleuze and Guattari's conception of minor literature. Minor literature, is, for Deleuze and Guattari, a kind of literature that is driven by a revolutionary goal to challenge the dominant despotic restrictions of majoritarian politics by means of literary arrangements and techniques (Kafka 28). Minor history is as such a form of history that is motivated by minoritarian politics to challenge the truthfulness and absoluteness of majoritarian history. Majoritarian history could be conceived as hystopia. It is majoritarian not quantitively but qualitatively. In other words, hystopia becomes majoritarian not because it fabulates the past of the masses but because its fabulation is remarkably despotic, authoritative and even fascistic in imposing that it is the one and only way of seeing the past. Likewise, minor history is minoritarian not only because it voices the unvoiced and the unheard in official histories but also because it downplays the absoluteness of hystopia by creating ruptures in its linear succession. In Eugene Holland's words, minor history could be seen as "[m]inoritarian becomings" that "strip away (or de-code) the actual determinations of the past and restore its virtual potential to become-otherwise" (26).

Barnes blatantly advocates the merits of minor history in lieu of hystopia in his works. In so doing, he employs the act of fabulation only to use it against itself. Thus, fabulation comes to function as a revolutionary tool to disrupt the linear, majoritarian and despotic nature of history. In The Fabulation of History, Ronald Bogue makes a useful definition of fabulation in historicization, which could be helpful to better comprehend Barnes's vocation of fabulation. For Bogue, it would be wrong to assume that "only historians and writers who subvert the forms of commonsense time could be considered fabulists, or that they engage in fabulation only at those moments when they problematise the temporal conventions of ordinary storytelling" (29-30), but rather "much of the power of their fabulation rests in their abilities as story tellers to engage with the stories of history" (30; emphasis added). However, it is important at this point to remember the difference between narration and story in Deleuzian terms. As Deleuze puts it in his Cinema 2: Time-Image, narration is a regime of laws "which determine successions, simultaneities and permanencies: it is a regime of localisable relations, actual linkages, legal, causal and logical connections" (126-127) whereas story is a regime in which "the virtual, for its part, detaches itself from its actualisations, starts to be valid for itself" (127). In narration, then, multiple temporalities that simultaneously exist yield to a linear succession whilst they retrieve back their virtual potentials in story. In Bogue's words, narration "reinforces the spatiotemporal structures of the common-sense world by subordinating time to regulated movement, whereas the story problematises those structures" (Bogue 30). In this regard, what this article calls hystopia is established and operates by the 
laws of narration whereas minor history relies on the laws of story. It is then the revolutionary act of fabulation that helps Barnes to move history to the pole of story in a Deleuzian sense.

Barnes's minor history concerns itself with an Aionic understanding of time that resists subordinating to regulated movement. Barnes presents history not in a linear succession but in a non-linear and even rhizomatic fashion. His resistance to a teleological ontology becomes most apparent in $A$ History of the World in 10 1/2 Chapters. The title of the novel suggests that the entire book will present a "history" of the world in the conventional way. But it turns out to be rhizomatically-scattered bits and pieces of the past that could not be ordered chronologically. The rhizomatic nature of Barnes's history of the world makes itself most apparent in the recurrent motifs in the novel. The woodworm who appears as a stowaway on Noah's Ark in the first chapter reappears as a culprit in the third chapter. Noah's Ark of the first chapter becomes the very subject of the ninth chapter, where the creationist astronaut Spike Tiggler decides to find it. While animals are categorised as clean and unclean on Noah's Ark in the first chapter, people are categorised as American and non-American on the Santa Euphemia hijacked by Palestinian terrorists. Likewise, Amanda Fergusson conducts a pilgrimage to Mount Ararat in the sixth chapter. Mount Ararat appears to be the destination of another spiritual journey in the ninth chapter as well. These zigzag movements between the chapters of world history necessarily create a rupture in the causal and linear lines of history. Another violation of linear temporality in history could be observed in Flaubert's Parrot, where Gustave Flaubert's personal past is filtered through different people's perceptions, primarily, that of Braithwaite. Each of these perceptions is shaped by the present and given in the form of zigzag movements between different temporalities, which in return creates inconsistencies between different narratives of the same past. In The Sense of an Ending, in a similar fashion, time's linear and sequential divisions are transcended. This time the main protagonist Tony Webster's personal past is displayed from his own perception. The first part of the novel treats Webster's past through the filters of his present self whilst the second part deals with his present that is constantly haunted by bits and pieces of his past. His representation of the past becomes a testimony to the fact that " $[\mathrm{m}]$ emory isn't linear, after all. It sorts and sifts more by priority than chronology" (Barnes "The Guardian Interview"). The rhizomatic and non-linear nature of history is detectable not only in each of Barnes's works individually but also in the organic relation between his works. Barnes enjoys rhizomatically distributing the same ideas and even the same phrases about history in different works. To exemplify a few, the idea that history burps first appears in A History of the World and then reappears in The Sense of an Ending with small variances as follows: '"History is a raw onion sandwich, sir.' 'For what reason?' 'It just repeats, sir. It burps. We've seen it again and again this year. Same old story, same old oscillation between tyranny and rebellion, war and peace, prosperity and impoverishment"' (17). Furthermore, the non-linear narrative structure of A History of the World is caricatured in the form of "A BRIEF HISTORY of 
sexuality in the case of Martha Cochrane" in England, England (50). Just in the same way Barnes presents fragments of world history in ten chapters and a parenthesis, he displays a history of sexuality in eight chapters and a parenthesis. In each case, history is not presented in the form of a complete narrative but in the form of a fragmented story.

Barnes reinforces the fragmentariness of his stories by presenting them from the perspectives of the minorities in hystopia. The minorities hereby do not designate those who are marginalised due to their identity-defining marks only. The minorities rather stand for the unvoiced and the unheard in official histories. It is not the captain but the stowaway, not the human but the animal, not the doctor but the patient, not the accuser but the accused that is heard throughout $A$ History of the World. In a similar vein, it is not the royals, queens and kings but pirates, bandits, folk heroes and writers that predominate the "Fifty Quintessences of Englishness" in England, England (86-97). This shows that Barnes writes history not with the voice of the standardised "people," but with the voice of what is missing, that is, with the voice of a "people to come" in Deleuzian sense. A people to come not only enables Barnes's work to take on a collective value but also helps it to minorise power dynamics and power relations operating in the appearance of official histories.

It is not simply these fragmented and rhizomatic stories that make Barnes's conception of history minoritarian. History in Barnes's work often draws lines of flight from hystopia and becomes minoritarian by exposing the processes of historiography and the impossibility of authentically translating the past events into a flawless narrative. To begin with the first argument, each of Barnes's novels at hand depicts all the problematic processes in which history is written, which is why each of them is described by many with Linda Hutcheon's coinage "historiographic metafiction" (105). Just as minor literature deterritorialises the inner mechanisms of a literary text, Barnes's minor history deterritorialises the inner mechanisms of historiography. Thus, just as language reaches its outside in minor literature, historiography reaches its outside in minor history. In both, the power of language and history is impoverished. In both, likewise, "expression [...] break[s] forms, mark[s] new ruptures and branchings. A form being broken, reconstruct the content that will necessarily be in rupture with the order of things" (Deleuze and Guattari Kafka 28). As for the second argument, it would be necessary to touch upon the Deleuzian conception of "event" to comprehend how the past is untranslatable in Barnes. For Deleuze, "event" does not correspond to what plainly happens but rather it suggests a becoming, a "moment of the state as a transformation" (Stagoll 87). As he puts it, every event is a moment in which all other events are interconnected or manifest their bits and pieces (Logic of Sense 34); therefore, every event is always more than a past happening: "With every event, there is indeed the present moment of its actualisation, the moment in which the event is embodied in a state of affairs, an individual, or a person, the moment we designate by saying 'here, the moment has come'" (151; emphasis in original). Historical event cannot be transmitted as a narrative in its entirety. This explains why each of Barnes's attempts to write history, be it a world 
history or a personal history, culminates in an intentional failure: A History of the World fails to truthfully chronicle "a history of the world," Flaubert's Parrot fails to truthfully chronicle Flaubert's life, England, England fails to truthfully chronicle a national history and The Sense of an Ending fails to truthfully chronicle personal memories. However, the moments in which these novels seem to fail depicting the past truthfully and authentically as they really happen correspond to the very moments in which their representation of the past becomes most eventful and minoritarian in a Deleuzian sense.

All these are tantamount to saying that Barnes engages in an overtly political project which would characterise both his position as a writer and his work as revolutionary. His work is revolutionary not only in unfolding majoritarian practices that linearise, hierarchise, authorise and fabulate the past but also in bringing about new and alternative paths to allow the zigzag movements of the past. At times when majoritarian politics operates in historiography in Barnes's work, history attains a despotic role, yielding the past to a succession and an ideological pattern. That is, history becomes a hystopia. Insofar as minoritarian politics is at work, history liberates the past from the hold of the authorities and is no longer domesticated into chronological sequence. That is, history becomes a minor history. Throughout his work, Barnes presents a genuine encounter between these two views of history, i.e. hystopia and minor history. Yet this is not an encounter of two entirely distinct zones. Hystopia and minor history are both a part of a productive and interconnected differential in Barnes. One cannot claim that Barnes's work is entirely purged of majoritarian logic that operates in the emergence of hystopia. On the contrary, he displays how exactly majoritarian logic works in the writing of history while at the same time replacing the arborescent systems born out of this logic. These moments of replacement correspond to the emergence of minor history. What does matter for Barnes is then to show these moments of encounter that move history from hystopia to minor history.

\section{Works Cited}

Barnes, Julian. A History of the World in 10 1/2 Chapters. Picador, 1989.

---. Flaubert's Parrot. Vintage Books, 2012.

---. The Sense of an Ending. Vintage Books, 2012.

--.. England, England. Vintage Books, 2000.

---. "Flaubert could have written a great novel about contemporary America": An Interview with Julian Barnes. https://www.theguardian.com/books/2018/jan/ 29/julian-barnes-interview-the-only-story Accessed 12 November 2018.

Baudrillard, Jean. Simulations. Translated by Paul Foss, Paul Patton, Philip Beitchman, Semiotext(e), 1983.

Bergson, Henri. Matter and Memory. Translated by Nancy Margaret Paul and W. Scott Palmer, Zone Books, 1991.

Bogue, Ronald. Deleuzian Fabulation and the Scars of History. Edinburgh UP, 2010.

Buxton, Jackie. "Julian Barnes's Theses on History (in 10 1/2 Chapters)," Contemporary Literature, vol. 41, no.1, Spring 2000.

Childs, Peter. Julian Barnes. Manchester UP, 2011. 
Colebrook, Claire. Gilles Deleuze. Routledge, 2002.

Deleuze, Gilles and Félix Guattari. Anti-Oedipus: Capitalism and Schizophrenia (1972). Translated by Robert Hurley, Mark Seem, and Helen R. Lane, U of Minnesota P, 1983.

---. A Thousand Plateaus: Capitalism and Schizophrenia (1980). Translated by Brian Massumi, U of Minnesota P, 1987.

---. What Is Philosophy? (1991). Translated by Hugh Tomlinson and Graham Burchell, Columbia UP, 1994.

---. Kafka: Toward a Minor Literature (1975). Translated by Dana Polan, U of Minnesota P., 2003.

Deleuze, Gilles. Bergsonism. Translated by Hugh Tomlinson and Barbara Habberjam, Zone Books, 1990.

---. The Logic of Sense (1969), edited by Constantin V. Boundas and translated by Mark Lester and Charles Stivale, Columbia UP, 1993.

---. Difference and Repetition (1968). Translated by Paul Patton, Columbia UP, 1994.

---. Essays: Critical and Clinical (1993). Translated by Daniel W. Smith and Michael A. Greco, U of Minnesota P, 1997.

Freiburg, Rudolf and Schnitker, Jan. "Do you consider yourself as a postmodern author?" Interviews with Contemporary English Writers. Transaction Publishers, 1999.

Guignery, Vanessa. "History in questions: An Interview with Julian Barnes," Sources (Orléans), vol. 8, Spring 2000.

---. The Fiction of Julian Barnes. Palgrave, Macmillan, 2006.

Head, Dominic. The Cambridge Guide to Literature in English. Cambridge UP, 2006.

Holland, Eugene. "Non-Linear Historical Materialism; Or, What is Revolutionary in Deleuze \& Guattari's Philosophy of History?" Time and History in Deleuze and Serres, edited by Bernd Herzogenrath, Continuum, 2012. pp.17-31.

Holmes, Frederick M. Julian Barnes. Palgrave Macmillan, 2009.

Hutcheon, Linda. A Poetic of Postmodernism: History, Theory, Fiction. Routledge, 1988.

Lampert, Jay. "Theory of Delay in Balibar, Freud and Deleuze: Decalage, Nachtraglichkeit, Retard." Deleuze and History, edited by Jeffrey A. Bell and Claire Colebrook, Edinburgh UP, 2009. pp.72-92.

Lundy, Craig. History and Becoming: Deleuze's Philosophy of Creativity. Edinburgh UP, 2012.

Pateman, Matthew. Julian Barnes. Northcote House, 2002.

Stagoll, Cliff. "Event." The Deleuze Dictionary: Revisited Edition, edited by Adrian Parr, Edinburgh UP, 2005.

Williams, James. Gilles Deleuze's Difference and Repetition: A Critical Introduction and Guide. Edinburgh UP, 2003. 